\title{
Increased Insulin Sensitivity in Patients with Anorexia Nervosa: The Role of Adipocytokines
}

\author{
I. DOSTÁLOVÁ ${ }^{1,2}$, K. SMITKA ${ }^{1}$, H. PAPEŽOVÁ ${ }^{3}$, H. KVASNIČKOVÁ ${ }^{1}$, \\ J. NEDVÍDKOVÁ ${ }^{1}$
}

${ }^{1}$ Institute of Endocrinology, ${ }^{2}$ Faculty of Natural Sciences, Charles University, Prague and

${ }^{3}$ Psychiatric Clinic, First Faculty of Medicine, Charles University, Prague, Czech Republic

Received October 15, 2006

Accepted September 26, 2006

On-line available December 19, 2006

\begin{abstract}
Summary
Anorexia nervosa (AN) is characterized by self-induced starvation leading to severe weight and fat loss. In the present study, we measured fasting plasma levels of adiponectin, leptin, resistin, insulin and glucose in 10 women with a restrictive type of AN and in 12 healthy women (C). Insulin sensitivity was determined according to homeostasis model assessment of insulin resistance (HOMA-R). Plasma resistin, leptin and insulin levels were significantly decreased, whereas plasma adiponectin levels were significantly increased in patients with AN compared to the C. HOMA-R was significantly decreased in patients with AN compared to the $\mathrm{C}$ group. Plasma adiponectin and leptin concentrations negatively and positively correlated with the body mass index and percentage body fat in both groups. Plasma adiponectin levels were negatively related to plasma insulin levels in the AN group only. In conclusion, we demonstrated that AN is associated with significantly decreased plasma leptin and resistin levels, markedly increased plasma adiponectin levels and increased insulin sensitivity. Plasma leptin and adiponectin levels were related to the body size and adiposity. Hyperadiponectinemia could play a role in increased insulin sensitivity of patients with AN. Neither body size and adiposity nor insulin sensitivity are the major determinants of plasma resistin levels in AN.
\end{abstract}

\section{Key words}

Anorexia nervosa $\bullet$ Adipocytokines $\bullet$ Insulin $\bullet$ HOMA-R

\section{Introduction}

It has been clearly demonstrated that the adipose tissue (AT) is a complex system that participates in energy homeostasis by releasing numerous metabolically active substances and hormones in response to specific extracellular stimuli. The term "adipocytokines" was recently coined to describe the adipose-derived bioactive factors modulating the physiological function of other tissues as well as acting in a paracrine manner on adipose tissue metabolism. Leptin, adiponectin $(\mathrm{ApN})$ and resistin are well known examples of adipocytokines that affect fuel homeostasis and insulin action (Brichard et al. 2003, Housa et al. 2006).

$\mathrm{ApN}$ is exclusively produced by adipocytes and has been found to be abundant in human circulation, with its plasma levels in the $\mu \mathrm{g} / \mathrm{ml}$ range (Arita et al. 1999). $\mathrm{ApN}$ has been clearly demonstrated to have a variety of functions, including antiatherogenic, antiinflammatory, and insulin-sensitizing properties (Yamauchi et al. 2002, 
Chen MP et al. 2005). In contrast to all other adipocytokines known to date, plasma ApN concentrations were paradoxically found to be decreased, not increased, in human obesity and type 2 diabetes, conditions commonly associated with insulin resistance and hyperinsulinemia (Weyer et al. 2001, Anderlová et al. 2006). Studies focused on the effect of long-term malnutrition of patients with anorexia nervosa (AN) on plasma ApN levels brought rather contradictory results, because its plasma levels were found to be either increased (Delporte et al. 2003, Housová et al. 2005, Nedvídková et al. 2005), decreased (Tagami et al. 2004) or unchanged (Iwahashi et al. 2003) in these patients.

Many experimental and clinical studies have shown that leptin is a key player in the regulation of food intake and energy balance (Montague et al. 1997). Leptin levels can be influenced by such conditions as satiety, amount of adipose tissue or diurnal cycles. These influences are mediated mostly by sympathetic regulators, insulin, glucocorticoids, and glucose entry into adipocytes (Coleman and Herrmann 1999). Among these factors, insulin has been shown to promote ob gene expression in adipocytes and to increase plasma leptin levels in humans (Kolaczynski et al. 1996). Although markedly reduced plasma leptin levels in patients with AN are well known (Nedvídková et al. 2000, Dostálová et al. 2005), the relationship between low plasma leptin levels and a degree of insulin sensitivity in these patients has not been fully elucidated.

Resistin has been suggested to suppress the ability of insulin to stimulate glucose uptake in rodents (Steppan and Lazar 2002). However, the physiological significance of resistin in humans is less clear (DegawaYamauchi et al. 2003). In humans, the major sources of resistin are immune and endothelial cells rather than adipocytes and it is not yet clear whether this peptide plays a significant role in the development of insulin resistance (IR) (Vettor et al. 2005). On this basis, the role of resistin in human has been shifted towards inflammatory and immune processes (Kunnari et al. 2006). Similarly to ApN, data on plasma resistin levels in AN are not unified, with plasma resistin levels found to be either decreased (Brichard et al. 2003, Dostálová et al. 2006) or unchanged (Housová et al. 2005) in patients with AN.

The above mentioned alterations of circulating adipocytokines may have potential repercussions in the pathophysiology of AN. Anorexia nervosa is a psychiatric disorder characterized by chronic self-induced starvation and severe weight loss, mainly at the expense of adipose tissue. As expected, AN is associated with altered glucose and lipid metabolism, multiple endocrine perturbations and other dysfunctions such as immune defects (Delporte et al. 2003). Studies reporting a degree of insulin sensitivity (IS) in AN provided rather contradictory results. Although majority of studies have found increased IS (Hermans and Lambert 2002, Delporte et al. 2003, Misra et al. 2004), either decreased (Pannacciulli et al. 2003) or unchanged (Castillo et al. 1985). IS in patients with AN have also been observed.

As adipocytokines are suggested to influence IS and available data on plasma levels of $\mathrm{ApN}$ and resistin as well as on the degree of IS in AN are rather contradictory, the aim of the present study was to investigate the relationship between circulating adipocytokines leptin, resistin and $\mathrm{ApN}$ and plasma insulin and glucose levels in patients with AN. To determine the degree of IS in patients with AN, we used homeostasis model assessment of insulin resistance (HOMA-R) that is based on the maintenance of a negative feedback loop between liver and pancreatic beta cells regulating both fasting glucose and insulin concentrations.

\section{Methods}

\section{Study subjects}

Ten women with a restrictive type of AN (age $24.4 \pm 1.6$ years; body mass index (BMI) $15.4 \pm 0.6 \mathrm{~kg} / \mathrm{m}^{2}$; percent body fat (\% BF) 4.1 \pm 0.9 ) and twelve healthy agematched women (C) (age 23.3 \pm 1.3 years; BMI 20.9 \pm 0.7 $\mathrm{kg} / \mathrm{m}^{2} ; \%$ BF $19.5 \pm 2.6$ ) were enrolled in the study. All subjects included in the study were non-smokers, had no allergies, and had been free of medication for at least three weeks prior to the study. Professional athletes were not included in the study. Control subjects had no history of obesity or malnutrition, hypertension, gastrointestinal disease, eating disorder or other psychiatric disorder, and had a normal physical examination and electrocardiogram (ECG). Blood tests confirmed normal blood count, liver and renal functions. Patients with AN were diagnosed according to the 4th edition of the Diagnostic and Statistical Manual of Mental Disorders (American Psychiatric Association, 1994) after detailed medical and psychiatric evaluation. All patients with a restrictive type of AN were examined after two weeks of hospitalization on the Department of Psychiatry and were clinically stable and in relatively good health, except for their 
Table 1. Anthropometric, hormonal and biochemical parameters of healthy control women $(C ; n=12)$ and of patients with anorexia nervosa ( $A N ; n=10)$.

\begin{tabular}{lll}
\hline & Controls $(\mathbf{n}=\mathbf{1 2})$ & Anorexia nervosa $(\mathbf{n}=\mathbf{1 0})$ \\
\hline Age $($ years $)$ & $23.3 \pm 1.3$ & $24.4 \pm 1.6$ \\
BMI $\left(\mathrm{kg} / \mathrm{m}^{2}\right)$ & $20.9 \pm 0.7$ & $15.4 \pm 0.6^{*}$ \\
$\%$ BF & $19.5 \pm 2.6$ & $4.1 \pm 0.9^{* * *}$ \\
Adipocytokines & & \\
Adiponectin $(\mu \mathrm{g} / \mathrm{ml})$ & $28.0 \pm 2.9$ & $46.4 \pm 5.0^{* *}$ \\
Leptin $(\mathrm{ng} / \mathrm{ml})$ & $10.8 \pm 1.1$ & $1.6 \pm 0.2^{* * *}$ \\
Resistin $(\mathrm{pg} / \mathrm{ml})$ & $312.2 \pm 17.1$ & $243.8 \pm 21.9^{*}$ \\
Glucose homeostasis & & \\
Glucose $(\mathrm{mmol} / \mathrm{l})$ & $4.6 \pm 0.1$ & $3.9 \pm 0.1$ \\
Insulin $(\mathrm{mIU} / \mathrm{l})$ & $4.5 \pm 0.2$ & $2.1 \pm 0.3^{*}$ \\
HOMA-R index & $0.89 \pm 0.1$ & $0.36 \pm 0.1^{*}$ \\
\hline
\end{tabular}

Values are means \pm S.E.M.; $\mathrm{n}=$ number of subjects; $\mathrm{BMI}=$ body mass index; $\% \mathrm{BF}=$ percent of body fat; HOMA-R = homeostasis model assessment of insulin resistance; $* \mathrm{P}<0.05, * * \mathrm{P}<0.01, * * * \mathrm{P}<0.001$ values significantly different from the $\mathrm{C}$ group.

eating disorder.

All healthy women were studied in day 7 to 10 of their menstrual cycle, whereas all patients with AN had amenorrhea. All subjects were asked to fast and drink only water on the night prior to the study. All participants provided written informed consent prior to participating in the study, which was approved by the Human Ethic Review Committee, Institute of Endocrinology, Prague, Czech Republic, and was performed in accordance with the guidelines proposed in the Declaration of Helsinki.

\section{Experimental procedures and blood sampling}

All subjects were admitted to the Institute of Endocrinology at 07:00 h. After a short medical examination (blood pressure, heart and respiratory rates measurement, ECG), \% BF was estimated by bioimpedance (TANITA, Japan). Blood samples for leptin, resistin, adiponectin, insulin and glucose evaluation were withdrawn at 08:00 h after $12 \mathrm{~h}$ of overnight fasting into chilled polypropylene tubes containing $\mathrm{Na}_{2}$ EDTA and antilysin. Plasma was immediately separated by centrifugation at $4{ }^{\circ} \mathrm{C}$ and stored at $-30^{\circ} \mathrm{C}$ until being assayed.

\section{Analytical procedures}

Plasma ApN and leptin were measured by commercial RIA kits (Linco Research, Inc., St. Charles, MO, USA). Sensitivity for ApN was $1 \mathrm{ng} / \mathrm{ml}$, and the intra- and interassay variability was $1.78 \%$ and $9.25 \%$, respectively. Sensitivity for leptin was $0.5 \mathrm{ng} / \mathrm{ml}$ and the intra- and interassay variability was $4.6 \%$ and $8.7 \%$, respectively. Plasma resistin was measured by a commercial resistin RIA kit (Phoenix Pharmaceuticals, Inc., Belmont, CA, USA). Sensitivity assay for resistin was $100 \mathrm{pg} / \mathrm{ml}$ and the intra- and interassay variability was $4.5 \%$ and $7.4 \%$, respectively. Plasma insulin was measured by a commercial RIA kit (Immunotech, Prague, Czech Republic). Sensitivity was $0.5 \mu \mathrm{IU} / \mathrm{ml}$ and the intra- and interassay variability was $3.4 \%$ and $4.3 \%$, respectively. Plasma glucose levels were measured on Cobas Integra 400 plus (Roche Diagnostics, GmbH, Mannheim, Germany). All assays were run twice in duplicate. Peripheral insulin resistance was determined using HOMA-R as previously described (Matthews et al. 1985 ) following the formula: fasting plasma insulin (mIU/l) $x$ fasting plasma glucose $(\mathrm{mmol} / \mathrm{l}) / 22.5$.

\section{Data analysis}

Results are presented as mean \pm S.E.M. MannWhitney test was used for group comparison. Correlations between parameters were examined using Spearman's rank correlation coefficient. $\mathrm{P}<0.05$ value denoted statistical significance.

\section{Results}

The anthropometric, hormonal and biochemical characteristics of the study subjects are shown in Table 1. BMI and fat mass were markedly reduced in AN compared to the control subjects. As shown in Table 1, 
Table 2. A, B. The relationship of leptin, resistin and adiponectin $(\mathrm{ApN})$ with anthropometric, biochemical, and hormonal parameters in patients with anorexia nervosa $(A)$ and in healthy control women $(B)$.

\begin{tabular}{|c|c|c|c|c|c|c|c|c|}
\hline A. & BMI & $\% \mathrm{BF}$ & Insulin & Glucose & HOMА & Leptin & Resistin & ApN \\
\hline \multirow[t]{2}{*}{ Leptin } & $\mathrm{R}=0.64$ & $\mathrm{R}=0.82$ & $\mathrm{R}=0.39$ & $\mathrm{R}=0.53$ & $\mathrm{R}=0.49$ & - & $\mathrm{R}=0.24$ & $\mathrm{R}=0.54$ \\
\hline & $\mathrm{P}=0.02$ & $\mathrm{P}=0.04$ & $\mathrm{P}=0.25$ & $\mathrm{P}=0.10$ & $\mathrm{P}=0.14$ & & $\mathrm{P}=0.52$ & $\mathrm{P}=0.24$ \\
\hline \multirow[t]{2}{*}{ Resistin } & $\mathrm{R}=0.27$ & $\mathrm{R}=0.17$ & $\mathrm{R}=0.59$ & $\mathrm{R}=0.39$ & $\mathrm{R}=0.29$ & $\mathrm{R}=0.24$ & - & $\mathrm{R}=-0.38$ \\
\hline & $\mathrm{P}=0.37$ & $\mathrm{P}=0.62$ & $\mathrm{P}=0.09$ & $\mathrm{P}=0.29$ & $\mathrm{P}=0.15$ & $\mathrm{P}=0.52$ & & $\mathrm{P}=0.29$ \\
\hline \multirow[t]{2}{*}{$A p N$} & $\mathrm{R}=-0.62$ & $\mathrm{R}=-0.49$ & $\mathrm{R}=-0.47$ & $\mathrm{R}=-0.62$ & $\mathrm{R}=-0.54$ & $\mathrm{R}=0.54$ & $\mathrm{R}=-0.38$ & - \\
\hline & $\mathrm{P}=0.03$ & $\mathrm{P}=0.01$ & $\mathrm{P}=0.01$ & $\mathrm{P}=0.09$ & $\mathrm{P}=0.15$ & $\mathrm{P}=0.24$ & $\mathrm{P}=0.29$ & \\
\hline B. & BMI & $\% B F$ & Insulin & Glucose & HOMA & Leptin & Resistin & ApN \\
\hline \multirow[t]{2}{*}{ Leptin } & $\mathrm{R}=0.52$ & $\mathrm{R}=0.49$ & $\mathrm{R}=0.31$ & $\mathrm{R}=0.55$ & $\mathrm{R}=0.38$ & - & $\mathrm{R}=0.17$ & $\mathrm{R}=0.16$ \\
\hline & $\mathrm{P}=0.01$ & $\mathrm{P}=0.02$ & $\mathrm{P}=0.27$ & $\mathrm{P}=0.08$ & $\mathrm{P}=0.16$ & & $\mathrm{P}=0.52$ & $\mathrm{P}=0.54$ \\
\hline \multirow[t]{2}{*}{ Resistin } & $\mathrm{R}=0.26$ & $\mathrm{R}=0.20$ & $\mathrm{R}=0.36$ & $\mathrm{R}=0.33$ & $\mathrm{R}=0.34$ & $\mathrm{R}=0.17$ & - & $\mathrm{R}=-0.29$ \\
\hline & $\mathrm{P}=0.34$ & $\mathrm{P}=0.46$ & $\mathrm{P}=0.19$ & $\mathrm{P}=0.23$ & $\mathrm{P}=0.22$ & $\mathrm{P}=0.52$ & & $\mathrm{P}=0.15$ \\
\hline \multirow[t]{2}{*}{$A p N$} & $\mathrm{R}=-0.45$ & $\mathrm{R}=-0.51$ & $\mathrm{R}=-0.36$ & $\mathrm{R}=-0.44$ & $\mathrm{R}=-0.32$ & $\mathrm{R}=0.16$ & $\mathrm{R}=-0.29$ & - \\
\hline & $\mathrm{P}=0.03$ & $\mathrm{P}=0.02$ & $\mathrm{P}=0.23$ & $\mathrm{P}=0.31$ & $\mathrm{P}=0.15$ & $\mathrm{P}=0.54$ & $\mathrm{P}=0.15$ & \\
\hline
\end{tabular}

Statistical significance from Spearman rank correlation test. BMI = body mass index; $\% B F=$ percent body fat; HOMA $=$ homeostasis model assessment of insulin resistance.

plasma ApN levels were significantly increased (46.4 5.0 vs. $28.0 \pm 2.9 \mu \mathrm{g} / \mathrm{ml}, \mathrm{P}<0.01)$, whereas plasma leptin and resistin concentrations were significantly decreased $(243.8 \pm 21.9$ vs. $312.2 \pm 17.1 \mathrm{pg} / \mathrm{ml}$ for resistin, $\mathrm{P}<0.05$; $1.6 \pm 0.2$ vs. $10.8 \pm 1.1 \mathrm{ng} / \mathrm{ml}$ for leptin, $\mathrm{P}<0.001)$ in patients with AN compared to the $\mathrm{C}$ group. Plasma insulin levels were significantly decreased in AN compared to the $\mathrm{C}$ subjects $(2.1 \pm 0.3 \mathrm{mIU} / 1$ vs. $4.5 \pm 0.24$, $\mathrm{P}<0.05$ ), whereas plasma glucose tended to be lower in $\mathrm{AN}$, but this decrease did not reach the statistical significance ( $3.9 \pm 0.1$ vs. $4.6 \pm 0.1 \mathrm{mmol} / \mathrm{l})$. HOMA-R index was significantly lower in the AN group in comparison with the $\mathrm{C}$ group $(0.36 \pm 0.06$ vs. $0.89 \pm 0.05$, $\mathrm{P}<0.05$ ) (Table 1).

Plasma adiponectin and leptin concentrations correlated negatively and positively with BMI and $\% \mathrm{BF}$ in both groups. Plasma ApN levels were negatively related to plasma insulin levels in the AN group, but not in the $\mathrm{C}$ group. We did not confirm significant relationship of resistin to any other parameters studied in either patients with $\mathrm{AN}$ or in the $\mathrm{C}$ group (Table $2 \mathrm{~A}, \mathrm{~B}$ ).

\section{Discussion}

We found significantly decreased plasma leptin and resistin levels and markedly increased plasma ApN levels in patients with AN. HOMA-R index was significantly decreased in patients with AN compared to the C. Plasma ApN and leptin levels were related to the nutritional status, whereas plasma resistin levels were not. Plasma ApN levels were negatively related to plasma insulin levels in the AN group only. Neither resistin nor leptin were related to increased IS in patients with AN.

The conflicting results of previous studies addressing the issue of IS in patients with AN may be partly attributable to differences in the techniques for evaluating insulin action. Using hyperinsulinemiceuglycemic clamp, insulin-stimulated glucose disposal has been reported to be normal (Castillo et al. 1985), varied (Kiriike et al. 1990) or decreased (Pannacciulli et al. 2003) in patients with AN. Using a minimal model by frequently sampled intravenous glucose tolerance test, Fukushima et al. (1993) found significantly increased IS in patients with AN. In the present study, we found normal plasma glucose and reduced plasma insulin levels together with low HOMA-R index in patients with AN suggesting that AN is associated with increased IS. These results are in agreement with previously published studies in AN using HOMA-R to determine IS under basal conditions (Delporte et al. 2003, Misra et al. 2004, Housová et al. 2005). As AN is associated with many endocrine and metabolic disturbances, the cause of 
increased IS in malnourished and hyperactive patients with AN might be multiple. Our finding of a negative relationship between plasma $\mathrm{ApN}$ and insulin has confirmed that increased IS in patients with AN can be related to hyperadiponectinemia found in these patients. Although Pannaciulli et al. (2003) hypothesized that hyperadiponectinemia might represent a compensatory mechanism for the reduced insulin-stimulated glucose metabolism in AN and Fasshauer et al. (2002) demonstrated that in vitro $\mathrm{ApN}$ gene expression is reversibly down-regulated by insulin, the insulinsensitizing effect of $\mathrm{ApN}$ administration in mice has repeatedly been demonstrated (Yamauchi et al. 2001). Thus, increased IS in patients with AN is probably secondary to hyperadiponectinemia induced by loss of fat mass in these patients.

One possible factor that could contribute to increased IS in patients with AN through the up- or down-regulation of adipocytokine production might be the activity of sympathoadrenal system (Fasshauer et al. 2001), previously demonstrated by our group to be markedly increased in vivo in the subcutaneous abdominal adipose tissue of patients with AN (Barták et al. 2004). An excess of growth hormone and cortisol, higher plasma free fatty acids levels together with betacell dysfunction associated with AN may also account for the altered glucose tolerance.

Studies focused on plasma ApN levels in patients with AN provided rather conflicting results. In agreement with the most of previously published studies (Pannacciulli et al. 2003, Housová et al. 2005), we found significantly increased plasma ApN levels in low-weight patients with AN compared to age- and sex-matched controls. Paradoxically, Yang et al. (2001) observed plasma ApN increase following body weight loss in obese humans and the authors explained this fact by fatness reduction. Similarly, the extreme reduction of fatness may be one of causes of ApN upregulation in AN. As both in vivo and in vitro studies indicated that fat mass may exert a negative feedback on its own ApN production by synthetizing a factor that destabilizes ApN mRNA (Delporte et al. 2003), the disturbance of such a negative feedback could contribute to hyperadiponectinemia observed in AN. This view is further supported by the observation of a negative correlation between plasma $\mathrm{ApN}$ and \% $\mathrm{BF}$ in patients with $\mathrm{AN}$ found in our study.

On the contrary to our results, Tagami et al. (2004) described significantly reduced plasma ApN levels in patients with AN compared to normal-weight controls and hypoadiponectinemia was reversed by weight recovery. Tagami et al. (2004) supposed that abnormal feeding behavior may affect some factors which down-regulate ApN, because they found equally low ApN levels in patients with AN and bulimia nervosa, regardless of their BMI. Although Iwahashi et al. (2003) did not observe any difference in ApN levels between AN and healthy women, this study pointed out the interesting fact that under the critical limit of body weight, the levels of $\mathrm{ApN}$ are lacking of inverse relationship to both BMI and \% BF. Recently, Bosy-Westphal et al. (2005) reported that the gain in fat mass is not associated with reduction of hyperadiponectinemia in AN, suggesting that other factors than the loss of body fatness may influence plasma ApN levels in AN.

At present there is no obvious explanation for such a discrepancy in published data for circulating ApN levels in patients with AN. However, two studies that described decreased (Tagami et al. 2004) or unchanged (Iwahashi et al. 2003) ApN levels in AN were performed on a Japanese population and patients included were older than in our study.

Numerous studies have previously described an important role of leptin in the regulation of food intake and energy homeostasis (Friedman et al. 2003). This study supports previous reports (Dostálová et al. 2005) that anorectic patients have significantly lower leptin levels than normal, thus suggesting that this cytokine is not involved in the reduction of food intake associated with AN, but reflects total body fat mass. We confirmed a positive correlation between plasma leptin and BMI, $\% \mathrm{BF}$ in patients with $\mathrm{AN}$ suggesting that the nutritional status is an important regulator of plasma leptin levels. However, we failed to find any relationship between reduced plasma leptin levels and enhanced IS in patients with AN. Although Misra et al. (2004) observed strong positive correlation between plasma leptin concentrations and IR in AN, the role of leptin in IS is still not fully understood (Schinner et al. 2005). However, we can not exclude a role of reduced leptin concentrations in determining the elevation of $\mathrm{ApN}$ plasma levels. It is well known that there are relevant interactions between leptin and other cytokines, these interactions could result in an additive, synergistic, or even antagonistic effect, thus suggesting the existence of positive and negative feedback systems dependent on cytokine-cytokine interactions (Loffreda et al. 1998).

Recently, resistin was identified in mouse 
adipocytes (Hartman et al. 2002) and this molecule was found to be overexpressed in obesity (Steppan and Lazar 2002). However, the role of resistin in human IR has not been clearly established. In some studies, resistin has been supposed to play a role in whole-body IR (Silha et al. 2003, Miner 2004), while others described no relationship between circulating resistin levels and IR (Chen CC et al. 2005, Chen MP et al. 2005, Farvid et al. 2005). In healthy normal-weight women, weight loss was not associated with alterations in circulating resistin levels (Wolfe et al. 2004). In agreement with Brichard et al. (2003) and contrary to Housová et al. (2005), we found significantly decreased plasma resistin levels in patients with AN. Such a discrepancy might be partly explained by differences in the study design (different time of blood withdrawal) as well as by characteristics of studied probands. Age and gonadal status as well as renutrition period of studied patients with AN were not clearly described in the study of Housová et al. (2005) and all these points could influence obtained data. However, our results confirmed the results of Housová et al. (2005) that circulating resistin levels are not related to IS and do not appear to be closely related to the nutritional status in patients with AN. One possible explanation of low plasma resistin levels in AN could be the defective mononuclear-macrophage number and/or function and decreased systemic inflammatory state (Brichard et al. 2003, Dostálová et al. 2006).

Overall, we are aware of the fact that a weak point of this study is the low number of probands included in the study that could lead to masking of some correlations. It should be further noted that not only the sensitivity to insulin, but also plasma levels of studied adipocytokines might be influenced by 14-day nutritional rehabilitation of patients with $\mathrm{AN}$, because the results of some studies suggested that glucose and insulin secretion are closely associated with body weight and eating behavior, and that these responses are reversible during nutritional rehabilitation (Tanaka et al. 2003). In general, the differences in the duration of nutritional rehabilitation together with wide range of individual persistence of the disorder of AN could contribute to a discrepancy in the published results.

In conclusion, we demonstrated that $\mathrm{AN}$ is associated with significantly decreased plasma leptin and resistin levels and markedly increased plasma adiponectin levels. Plasma leptin and adiponectin levels were related to the body size and adiposity. Hyperadiponectinemia in patients with AN could play a role in increased IS found in these patients. The role of reduced plasma resistin levels in anorexia nervosa needs further investigation. However, neither insulin sensitivity nor body size and adiposity are major determinants of plasma resistin levels in patients with AN.

\section{Acknowledgements}

This study was supported by the grant agency of the Ministry of Health CR, No. NR/91583. We would like to thank Mrs. Diana Riegerová, Jana Novotná and Romana Bajtlová for their technical assistance.

\section{References}

ANDERLOVÁ K, KŘEMEN J, DOLEŽALOVÁ R, HOUSOVÁ J, HALUZÍKOVÁ D, KUNEŠOVÁ M, HALUZÍK M: The influence of very-low-calorie diet on serum leptin, soluble leptin receptor, adiponectin and resistin levels in obese women. Physiol Res 55: 277-283, 2006.

ARITA Y, KIHARA S, OUCHI N, TAKAHASHI M, MAEDA K, MIYAGAWA J, HOTTA K, SHIMOMURA I, NAKAMURA T, MIYAOKA K, KURIYAMA H, NISHIDA M, YAMASHITA S, OKUBO K, MATSUBARA K, MURAGUCHI M, OHMOTO Y, FUNAHASHI T, MATSUZAWA Y: Paradoxical decrease of an adipocyte specific protein, adiponectin, in obesity. Biochem Biophys Res Commun 257: 79-83, 1999.

BARTÁK V, VYBÍRAL S, PAPEŽOVÁ H, DOSTÁLOVÁ I, PACÁK K, NEDVÍDKOVÁ J: Basal and exercise induced sympathetic nervous activity and lipolysis in adipose tissue of patients with anorexia nervosa. Eur $J$ Clin Invest 34: 371-377, 2004.

BOSY-WESTPHAL A, BRABANT G, HAAS V, ONUR S, PAUL T, NUTZINGER D: Determinants of plasma adiponectin levels in patients with anorexia nervosa examined before and after weight gain. Eur $J$ Nutr 44: 355-359, 2005.

BRICHARD SM, DELPORTE ML, LAMBERT M: Adipocytokines in anorexia nervosa: a review focusing on leptin and adiponectin. Horm Metab Res 35: 337-342, 2003. 
CASTILLO M, SCHEEN A, LEFEBVRE PJ, LUYCKS AS: Insulin-stimulated glucose disposal is not increased in anorexia nervosa. J Clin Endocrinol Metab 60: 311-314, 1985.

CHEN CC, LI TC, LI CI, LIU CHS, WANG HJ, LIN CC: Serum resistin level among healthy subjects: relationship to anthropometric and metabolic parameters. Metabolism 54: 471-475, 2005.

CHEN MP, TSAI JC, CHUNG FM, YANG SS, HSING LL, SHIN SJ, LEE YJ: Hypoadiponectinemia is associated with ischemic cerebrovascular disease. Arterioscler Thromb Vasc Biol 25: 821-826, 2005.

COLEMAN RA, HERRMANN TS: Nutritional regulation of leptin in humans. Diabetologia 42: 639-646, 1999.

DELPORTE ML, BRICHARD SM, HERMANS MP, BEGUIN C, LAMBERT M: Hyperadiponectinaemia in anorexia nervosa. Clin Endocrinol 58: 22-29, 2003.

DEGAWA-YAMAUCHI M, BOVENKERK JE, JULIAR BE, WATSON W: Serum resistin (FIZZ3) protein is increased in obese humans. J Clin Endocrinol Metab 88: 5452-5455, 2003.

DOSTÁLOVÁ I, KOPSKÝ V, DUŠKOVÁ J, PAPEŽOVÁ H, PACÁK K, NEDVÍDKOVÁ J: Leptin concentrations in the abdominal subcutaneous adipose tissue of patients with anorexia nervosa assessed by in vivo microdialysis. Regul Pept 128: 63-68, 2005.

DOSTÁLOVÁ I, KUNEŠOVÁ M, DUŠKOVÁ J, PAPEŽOVÁ H, NEDVÍDKOVÁ J: Adipose tissue resistin levels in patients with anorexia nervosa. Nutrition 22: 977-983, 2006.

FARVID MS, NG TW, CHAN DC, BARRETT PH, WATTS GF: Association of adiponectin and resistin with adipose tissue compartments, insulin resistence and dyslipidaemia. Diabetes Obes Metab 7: 406-413, 2005.

FASSHAUER M, KLEIN J, NEUMANN S, ESZLINGER M, PASCHKE R: Adiponectin gene expression is inhibited by beta-adrenergic stimulation via protein kinase A in 3T3-L1 adipocytes. FEBS Lett 507: 142-146, 2001.

FASSHAUER M, KLEIN J, NEUMANN S, ESZLINGER N, PASCHKE R: Hormonal regulation of adiponectin gene expression in 3T3-L1 adipocytes. Biochem Biophys Res Commun 290: 1084-1089, 2002.

FUKUSHIMA M, NAKAI Y, TANIGUCHI A, IMURA H, NAGATA I, TOKUYAMA K: Insulin sensitivity, insulin secretion, and glucose effectiveness in anorexia nervosa: a minimal model analysis. Metab 42: 1164-1168, 1993.

FRIEDMAN JM: A war on obesity, not the obese. Science 299: 856-858, 2003.

HARTMAN HB, HU X, TYLER KX, DALAL CK, LAZAR MA: Mechanisms regulating adipocyte expression of resistin. J Biol Chem 277: 19754-19761, 2002.

HERMANS MP, LAMBERT MJ: HOMA-modelling of insulin sensitivity and beta-cell function in anorexia nervosa. Eur Eat Disord Rev 10: 41-50, 2002.

HOUSA D, HOUSOVÁ J, VERNEROVÁ Z, HALUZÍK M: Adipocytokines and cancer. Physiol Res 55: 233-244, 2006.

HOUSOVÁ J, ANDERLOVÁ K, KŘÍŽOVÁ J, HALUZÍKOVÁ D, KŘEMEN J, KUMŠTÝŘOVÁ T, PAPEŽOVÁ H, HALUZÍK M: Serum adiponectin and resistin concentrations in patients with restrictive and binge/purge form of anorexia nervosa and bulimia nervosa. J Clin Endocrinol Metab 90: 1366-1370, 2005.

IWAHASHI H, FUNAHASHI T, KUROKAWA N, SAYAMA K, FUKUDA E, OKITA K, IMAGAWA A, YAMAGATA K, SHIMOMURA I, MIYAGAWA JI, MATSUZAWA Y: Plasma adiponectin levels in women with anorexia nervosa. Horm Metab Res 35: 537-540, 2003.

KIRIIKE A, NISHIWAKI S, NAGATA T, OKUNO Y, YAMADA J, TANAKA S, FUJII A, KAWAKITA Y: Insulin sensitivity in patients with anorexia nervosa and bulimia. Acta Psychiatr Scand 81: 236-239, 1990.

KOLACZYNSKI JW, NYCE MR, CONSIDINE RV: Acute and chronic effect of insulin on leptin production in humans. Studies in vivo and in vitro. Diabetes 45: 699-701, 1996.

KUNNARI A, UKKOLA O, PAIVANSALO M, KESANIEMI YA: High plasma resistin level is associated with enhanced highly sensitive C-reactive protein and leukocytes. J Clin Endocrinol Metab 91: 2755-2760, 2006.

LOFFREDA S, YANG SQ, LIN HZ, KARP CL, BRENGMAN ML, WANG DJ, KLEIN AS, BULKLEY GB, BAO C, NOBLE PW, LANE MD, DIEHL AM: Leptin regulates proinflammatory immune responses. FASEB $J$ 12: 57-65, 1998.

MATTHEWS DR, HOSKER JP, RUDENSKI AS, NAYLOR BA, TREACHER DF, TURNER RC: Homeostasis model assessment: insulin resistance and beta-cell function from fasting plasma glucose and insulin concentrations in man. Diabetologia 28: 412-419, 1985. 
MINER JL: The adipocyte as an endocrine cell. J Anim Sci 82: 935-941, 2004.

MISRA M, MILLER KK, ALMAZAN C, RAMASWAMY K, AGGARWAL A, HERZOG DB, NEUBAUER G, BREU J, KLIBANSKI A: Hormonal and body composition predictors of soluble leptin receptor, leptin and free leptin index in adolescent girls with anorexia nervosa and controls and relation to insulin sensitivity. $J$ Clin Endocrinol Metab 89: 3486-3495, 2004.

MONTAGUE CT, FAROOQI IS, WHITEHEAD JP, SOOS MA, RAU H, WAREHAM NJ, SEWTER CP, DIGBY JE, MOHAMMED SN, HURST JA, CHEETHAM CH, EARLEY AR, BARNETT AH, PRINS JB, O'RAHILLY $\mathrm{S}$ : Congenital leptin deficiency is associated with severe early-onset obesity in humans. Nature 387: 903-908, 1997.

NEDVÍDKOVÁ J, PAPEŽOVÁ H, HALUZÍK M, SCHREIBER V: Interaction between serum leptin levels and hypothalamo-hypophyseal-thyroid axis in patients with anorexia nervosa. Endocr Res 26: 219-230, 2000.

NEDVÍDKOVÁ J, SMITKA K, KOPSKÝ V, HAINER V: Adiponectin, an adipocyte-derived protein. Physiol Res 54: 133-140, 2005.

PANNACCIULLI N, VETTOR R, MILAN G, GRANZOTTO M, CATUCCI A, FEDERSPIL G, DE GIACOMO P, GIORGINO R, DE PERGOLAG: Anorexia nervosa is characterized by increased adiponectin plasma levels and reduced nonoxidative glucose metabolism. J Clin Endocrinol Metab 88: 1748-1752, 2003.

SCHINNER S, SCHERBAUM WA, BORNSTEIN SR, BARTHEL A: Molecular mechanisms of insulin resistance. Diabet Med 22: 674-682, 2005.

SILHA JV, KRŠEK M, ŠKRHA JV, SUCHARDA P, NYOMBA BL, MURPHY LJ: Plasma resistin, adiponectin and leptin levels in lean and obese subjects: correlations with insulin resistance. Eur J Endocrinol 149: 331-335, 2003.

STEPPAN CM, LAZAR MA: Resistin and obesity-associated insulin resistance. Trends Endocrinol Metab 13: 18-23, 2002.

TAGAMI T, SATOH N, USUI T, YAMADA K, SHIMATSU A, KUZUYA H: Adiponectin in anorexia nervosa and bulimia nervosa. J Clin Endocrinol Metab 89: 1833-1837, 2004.

TANAKA M, TATEBE Y, NAKAHARA T, YASUHARA D, SAGIYAMA K: Eating pattern and the effect of oral glucose on ghrelin and insulin secretion in patients with anorexia nervosa. Clin Endocrinol 59: 574-579, 2003.

VETTOR R, MILAN G, ROSSATO M, FEDERSPIL G: Adipocytokines and insulin resistance. Aliment Pharmacol Ther 22: 3-10, 2005.

WEYER C, FUNAHASHI T, TANAKA S, HOTTA K, MATSUZAWA Y, PRATLEY RE, TATARANNI PA: Hypoadiponectinemia in obesity and type 2 diabetes: close association with insulin resistance and hyperinsulinemia. J Clin Endocrinol Metab 86: 1930-1935, 2001.

WOLFE BA, JIMERSON DC, ORLOVA CH, MANTZOROS CHS: Effect of dieting on plasma leptin, soluble leptin receptor, adiponectin and resistin levels in healthy volunteers. Clin Endocrinol 61: 332-338, 2004.

YAMAUCHI T, KAMON J, WAKI H, TERAUCHI Y, KUBOTA N, HARA K, MORI Y, IDE T, MURAKAMI K, TSUBOYAMA-KASAOKA N, EZAKI O, AKANUMA Y, GAVRILOVA O, VINSON C, REITMAN ML, KAGECHIKA H, SHUDO K, YODA M, NAKANO Y, TOBE K, NAGAI R, KIMURA S, TOMITA M, FROGUEL P, KADOWAKI T: The fat-derived hormone adiponectin reverses insulin resistance associated with both lipoatrophy and obesity. Nat Med 7: 941-946, 2001.

YAMAUCHI T, KAMON J, MINOKOSHI Y, YTO Y, WAKI H, UCHIDA S, YAMASHITA S, NODA M, KITA S, UEKI K, ETO K, AKANUMA Y, FROGUEL P, FOUFELLE F, FERRE P, CARLING D, KIMURA S, NAGAI R, KAHN BB, KADOWAKI T: Adiponectin stimulates glucose utilization and fatty-acid oxidation by activating AMP-activated protein kinase. Nat Med 8: 1288-1295, 2002.

YANG WS, LEE WJ, FUNAHASHI T, TANAKA S, MATSUZAWA Y, CHAO CL, CHEN CL, TAI TY, CHUANG LM: Weight reduction increases plasma levels of an adipose-derived anti-inflammatory protein, adiponectin. J Clin Endocrinol Metab 86: 3815-3819, 2001.

\section{Corresponding author}

Ivana Dostálová, Institute of Endocrinology, Národní 8, 11694 Prague 1, Czech Republic. Fax: + 420-224905325. E-mail: idostalova@endo.cz 